\title{
Growth of selected fungi on biodegradable films
}

\author{
Agnieszka Richert ${ }^{1 *}$, Ewa Olewnik-Kruszkowska ${ }^{2}$, Iwona Tarach ${ }^{2}$ \\ ${ }^{1}$ Institute for Engineering of Polymer Materials and Dyes, $55 \mathrm{M}$. Skłodowskiej-Curie St, \\ 87-100 Toruń, Poland \\ ${ }^{2}$ Nicolaus Copernicus University, Faculty of Chemistry, Chair of Physical Chemistry and Physicochemistry \\ of Polymers, Gagarin 7 St, 87-100 Toruń, Poland, \\ e-mail: a.richert@impib.pl
}

Received: 16 March 2018 / Accepted: 26 June 2018

\begin{abstract}
This study presents the data summary on growth speed of selected species of fungi on some of biodegradable polymer materials. Growth rate was assessed on films composed of poly(lactide), poly( $\varepsilon$-caprolactone) and poly(hydroxybutyrate) after a month of incubation in $24^{\circ} \mathrm{C}$. To assess growth of fungi optical microscopy on densitometric measurements were used. Through these analyses the best growth was confirmed for fungus: Chaetomium globosum (ATTC 6205) on a film made of poly( $\varepsilon$-caprolactone).
\end{abstract}

Keywords: fungi, poly(lactide), poli( $\varepsilon$-caprolactone), poly(hydroxybutyrate), biodegradable films.

\section{Introduction}

Polymeric materials play an important role in industry as they have been used for decades in packaging, architecture and medical industry (Kumar et al., 2007; Shah et al., 2008; Żakowska, 2009; Richert, 2017). For the last few years biodegradable polymeric materials are specifically gaining interest (Shogren, 1997; Hakkarainem et al., 2000; Tsuji et al., 2006; Rhim, 2009; Strömberg \& Karlsson, 2009; Richert, 2017). Biodegradable polymers can be obtained from crude oil like poly( $\varepsilon$-caprolactone) (PCL) or from renewable resources, which is characteristic for aliphatic polyesters such as poly(lactide) (PLA) and poly(hydroxybutyrate) (PHB) (Manna, 2000; Tokiwa \& Calabia, 2006; Wada et al., 2007; Morawska \& Krasowska, 2017; Qi et al., 2017). The most common among biodegradable polyesters is PLA. It undergoes complete biodegradation in the time span of 6 to 24 months (Tokiwa \& Calabia, 2006; Richert, 2017). PCL is used very commonly as a biodegradable component of many different films, and it accelerates their degradation
(Tokiwa \& Calabia, 2006). PHB is known in microbiology as a reserve material of numerous bacteria and its concentration in bacterial cells varies from 1 to $30 \%$ of dry matter (Jayasekara et al., 2005).

The aim of the analyses was to select the species which are the most beneficial for processes of biodegradation of polymeric materials such as: PLA, PCL and PHB. The attempt was made to select fungi whose growth would be possible in the presence of biodegradable polymeric materials.

\section{Material and methods}

The subject of the study was biodegradable films made of:

a) Poly(lactide) (PLA), type 2003 D (NatureWorks ${ }^{\circledR}$, USA). Material marked with symbol (PLA);

b) Poly( $\varepsilon$-caprolactone), type $\mathrm{CAPA}^{\mathrm{TM}}$ FB100 (Rerstorp, UK). Material marked with symbol (PCL); 
c) SoGreen ${ }^{\circledR}$-2001a (Tianjin Green BioMaterial Company, China) a polymeric mixture composed of poly(3.4-hydroxybutyrate) and poly(lactide). Material marked with symbol (PHB).

The subject of the study was also microorganisms. In this study six strains of fungi from worldwide (ATCC) and Polish (IOR) collections were used. As these fungi are used in microbiological tests that aim at assessing their effect on plastics (PN EN ISO 846 (2014); PN EN 15457 (2014)), there emerged a research need to test and verify these microorganisms against biodegradable polymeric materials. The following types of strains were used for this study: Chaetomium globosum (ATTC 6205), Fusarium culmorum (IOR 1913), Penicillium pinophilum (ATCC 36839), Paecilomyces variotti (ATCC 18502), Trichoderma viridae (ATCC 9645), Aspergillus niger (ATCC 6275).

Cultures of every fungal strain were established in Petri dishes containing optimal agar medium with the composition according to the norm PN EN ISO 846 (2014). The cultures were maintained in $24^{\circ} \mathrm{C}$ for 1 week. After this time, suspensions with $1.5 \cdot 10^{8}$ spores $/ \mathrm{ml}$ were prepared (PN EN ISO 846 (2014); PN EN 15457 (2014)). Later,
$100 \mu \mathrm{l}$ of suspension from every strain of fungi were used to inoculate test tubes with Czapek-Dox no glucose medium with the composition $[\mathrm{g} / \mathrm{l}]: \mathrm{MgSO}_{4} \cdot 7 \mathrm{H}_{2} \mathrm{O}-5.0, \mathrm{Na}_{2} \mathrm{H}-$ $\mathrm{PO}_{4}-1.0, \mathrm{KCL}-0.5, \mathrm{NaNO}_{3}-3.0, \mathrm{Fe}\left(\mathrm{SO}_{4}\right)_{3} \cdot 7 \mathrm{H}_{2} \mathrm{O}-0.01$, agar - 15.0. Two test series were prepared:

1. Control samples, which consisted of medium with fungus inoculum (symbol in Figure 1: "Fungi").

2. Test samples, which, apart from medium and fungus inoculum, also included tested film fragments sized $1.5 \mathrm{~cm}$ x $1.5 \mathrm{~cm}$ (symbols in Figure 1: "PLA + fungi", "PCL + fungi", "PHB + fungi").

The experiment was conducted in three repeats for every configuration. Such prepared cultures were incubated in $24^{\circ} \mathrm{C}$ on laboratory shaker Unimax 1010 with heating module (Heidolph) [100 rpm] for a month. After this time, optical density of suspensions was measured and microscopy analyses were performed.

Turbimetric measurements were conducted on DensiLa-Meter ${ }^{\circledR}$ II (Erba Lachema) densitometer. In microbiology, McFarland Standards are used as a reference to adjust the turbidity of microbial suspensions (Libudisz et al., 2009; PN EN ISO 846 (2014)). Table 1 shows the McFarland Standards.

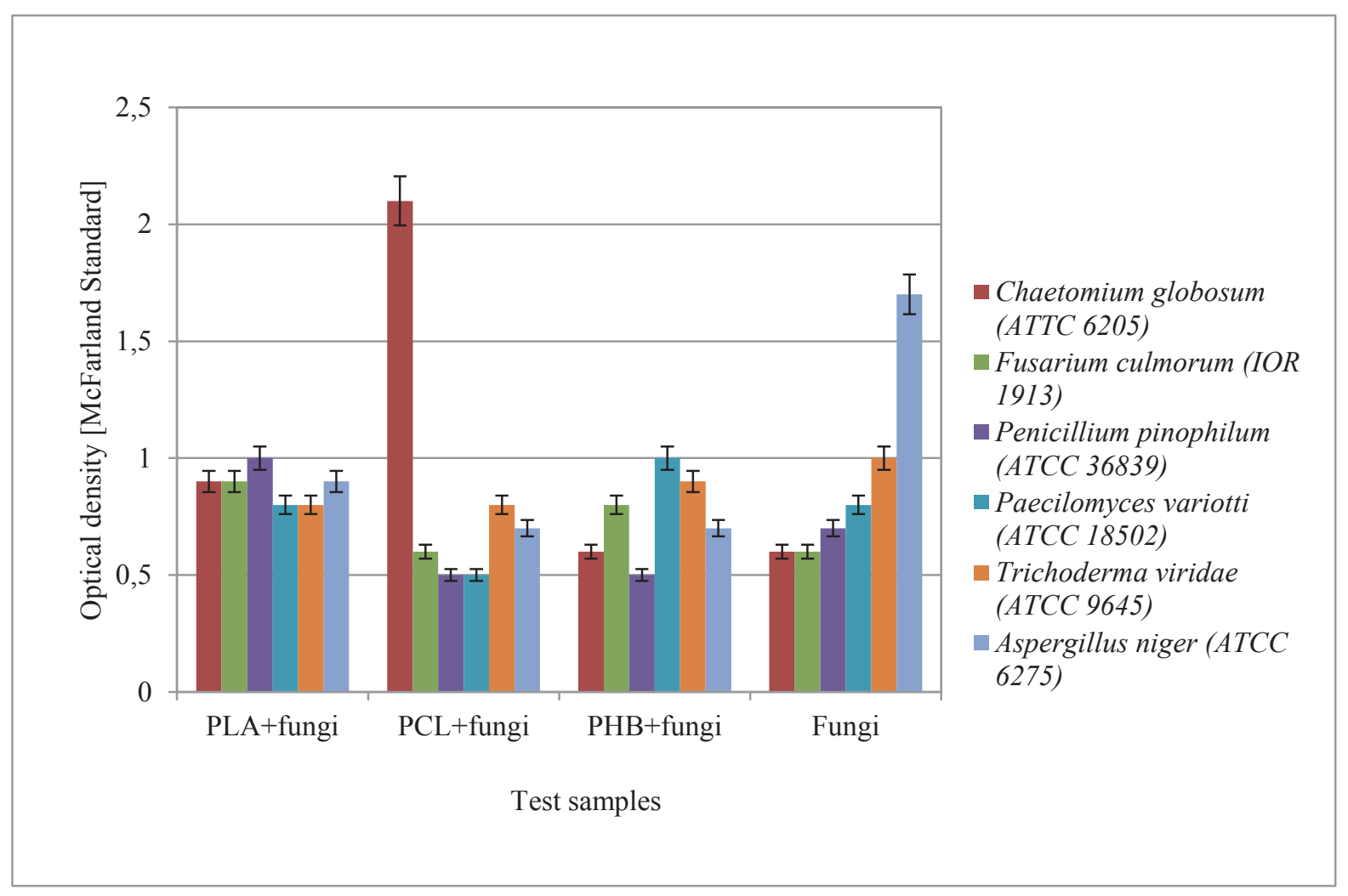

Figure 1. Optical density of the culture fluid after a monthly incubation in the presence of samples PLA, PCL, PHB and fungi as well as the fungi themselves 
Table 1. McFarland Standards

\begin{tabular}{|c|c|}
\hline McFarland Standards & Approximate microbial suspension/ml \\
\hline 0.5 & $1.5 \cdot 10^{8}$ \\
\hline 1.0 & $3.0 \cdot 10^{8}$ \\
\hline 2.0 & $6.0 \cdot 10^{8}$ \\
\hline 3.0 & $9.0 \cdot 10^{8}$ \\
\hline
\end{tabular}

Microscopic observations of mycelium growth on the films were conducted with the use of Olympus SZX12 stereoscopic microscope with image magnification 120x, with ARTRAY Model ARTCAM 300MI camera.

\section{Results and discussion}

The results of measurements of optical density of films in the presence of fungi are shown on Figure 1. It describes differences between the optical density of medium containing test materials (PLA, PCL, PHB) and fungi, and the medium containing only fungi: Chaetomium globosum (ATTC 6205), Fusarium culmorum (IOR 1913), Penicillium pinophilum (ATCC 36839), Paecilomyces variotti (ATCC 18502), Trichoderma viridae (ATCC 9645), Aspergillus niger (ATCC 6275). Table 2 shows compared results of changes on the surfaces of films under the influence of six strains of fungi.

In Figure 1, changes in the growth of individual fungal strains were observed depending on the type of material tested. Analysis of changes in the surface structure (Table 2) confirmed the highest activity of the Chaetomium globosum strain, which was characterized by the largest increase on the surface of the PCL film.

In our research it was proved that the fungi that best developed on the film made of poly( $\varepsilon$-caprolatone) (PCL) was: Chaetomium globosum (ATTC 6205) (Fig. 1, Table 2), it has the highest optical density above 2 McFarland (Fig. 1). I turn, Fusarium culmorum (IOR 1913) was the most grown on the surface of films marked as PLA and PHB. In several cases (Fig. 1), a higher optical density was noted in case of a variant containing only medium and fungal inoculum (without a film). These results indicate that fungi Trichoderma viridae (ATCC 9645) and Aspergillus niger (ATCC 6275) do not degrade PLA, fungi Paecilomyces variotti (ATCC 18502), Penicillium pinophilum (ATCC 36839) and Aspergillus niger (ATCC 6275) do not decompose PCL, nor do they degrade the material marked with the PHB symbol.

Presented result of this study (Fig. 1, Table 2) concerning growth of fungi on the surface of biodegradable poly- meric materials prove that both environment of culture and material are not without a meaning for the process of fungi growth. This is particularly evident for PLA, PCL and PLA, PHB samples where the growth of Chetomium globosum and Fusarium culmorum, respectively, is the highest compared to other microorganisms (Table 2).

Material susceptibility to biodegradation is verified with use of normalised research methods. Each of these techniques consists in submitting the polymeric material to the microorganisms. Microorganism growth on the film sample is tested on liquid and solid surface depending on the experimental technique. Very often, such analyses use medium that does not contain a carbon source (Jayasekara et al., 2005).

Levinskaite (2018) research showed that the fungi Penicillinum. chrysogenum, P. spinulosum, P. verruculosum, and $P$. variabile developed well on the majority of the substrata such as paraffin, chitin, leather. The use of the tested substrata shows that most of these fungi, isolated from materials hardly suitable to fungal nutritive requirements, can utilize different carbon sources. According the author These fungi can be considered good decomposers of materials occurring in nature as wastes.

The development of fungi on polymeric materials can be determined using different techniques, the growth of microorganisms itself depends mostly on experimental conditions (Redlak et al., 2001; Morawska \& Krasowska, 2017). It should be noted, however, that unification of experimental conditions for different strains can be problematic. According to Nishida \& Tokiwa (1993), determination of microorganism quantity is an effective and proper method of assessing the suitability of a strain in polymeric material biodegradation.

Araceli et al. (2011) proved that out of several fungi examined, Aspergillus flavus (ATCC 6051) caused a polyurethane mass decrease by over $60 \%$ after a month of incubation. Torres et al. (1996) while conducting research on PLA proved that only two out of fourteen strains (Fusarium moniliforme i Penicillium roqueforti) showed the ability to use PLA lactic acid. By 2006, the Tritirachium album (synonym Engyodontium album) was the only described fungus degrading L-PLA (Tokiwa \& Calabia, 2006). 
Table 2. Analysis of changes in surfaces of the films after month of incubation with fungi (the largest growth of fungi was marked with the arrows)

\begin{tabular}{|c|c|c|c|}
\hline & PLA & PCL & PHB \\
\hline $\begin{array}{l}\text { Control } \\
\text { (without fungi) }\end{array}$ & & & \\
\hline $\begin{array}{l}\text { Chaetomium globosum } \\
\text { (ATTC 6205) }\end{array}$ & & & \\
\hline Fusarium culmorum (IOR 1913) & & & \\
\hline $\begin{array}{l}\text { Penicillium pinophilum } \\
\text { (ATCC 36839) }\end{array}$ & & & \\
\hline $\begin{array}{l}\text { Paecilomyces variotti } \\
\text { (ATCC 18502) }\end{array}$ & & & \\
\hline $\begin{array}{l}\text { Trichoderma viridae } \\
\text { (ATCC 9645) }\end{array}$ & & & \\
\hline Aspergillus niger (ATCC 6275) & & & \\
\hline
\end{tabular}


Dey et al. (2012) research showed that in incubated films in the presence of microorganisms, changes appear in form of cracks, pores, crevices, bulges, holes, dark spots and the presence of microorganisms themselves, which can colonise a given surface of the film and create a biofilm. In the study Janczak et al. (2014) growth of the fungi such as Clitocyte, Laccaria laccata and Trichoderma viridae on type of films: polyethylene (PE), poly(ethylene terephthalate) (PET), polycaprolactone (PCL), polylactide (PLA), polyhydroxybutyrate (PHB) was analysed. Laccaria laccata showed the highest growth activity on polymers. The analysis with the microscope confirmed the highest activity of this fungi. On the surface of PCL, especially were visible deep cracks. In our research the highest activity of fungi (Chaetomium globosum and Trichoderma viridae) also was observed on PCL surface.

Numerous scientific papers on the search for fungi capable of growing on polymeric materials indicate the need for this kind of research (Torres et al., 1996; Dey et al., 2012; Morawska \& Krasowska, 2017; Apetrei et al., 2018; Barnharst et al., 2018; Gibas et al., 2018; Levinskaite, 2018). Due to the protection of natural environment, especially heathlands, including plants and lichens (Adamska \& Deptuła, 2015a, 2015b; Adamska et al., 2015), it seems appropriate to look for new recycling methods. It is also necessary to search for microorganisms capable of settling in the environment burdened with polymeric waste and to use them for waste utilisation through biodegradation processes (Tokiwa \& Calabia, 2006).

\section{Conclusion}

The applied method allowed to evaluate the tested fungal strains in terms of their use in biodegradation processes. The fungi that was the most developed on the surface of PCL was Chaetomium globosum, while on the surface of PLA and PHB it was Fusarium culmorum. The analysis of the surface of the film carried out with the use of an optical microscope confirmed in a fairly good way the results of the research obtained from densitometric measurements.

\section{References}

Adamska E. \& Deptuła M., 2015a, Epigenist lichens of different development stages of forest growing on the heathland. Ecological Questions 21: 39-44.

Adamska E. \& Deptuła M., 2015b, Materials for biota of lichens and lichenicolous fungi in the military area near Toruń, Poland. Ecological Questions 21: 45-53.

Adamska E., Deptuła M., Filbrandt-Czaja A., Kamiński D., Lewandowska-Czarnecka A., Nienartowicz A. \& Sewerniak P., 2015, Heathlands and associated communi- ties in Kujawy and Pomerania: management, treatment and conservation. Towarzystwo Naukowe w Toruniu, Torun.

Apetrei R-M., Carac G., Bahrim G., Ramanaviciene A. \& Ramanavicius A., 2018, Modification of Aspergillus niger by conducting polymer, Polypyrrole, and the evaluation of electrochemical properties of modified cells. Bioelectrochemistry 121: 46-55.

Araceli L.T., Gilberto G., Abraham V.T., Raúl R.H. \& Cristóbal N.A., 2011, Polyurethane foam as substrate for fungal strains. Advances in Bioscience and Biotechnology 2: 52-58.

Barnharst T., Rajendran A. \& Hu B., 2018, Bioremediation of synthetic intensive aquaculture wastewater by a novel feed-grade composite biofilm. International Biodeterioration \& Biodegradation 126: 131-142.

Dey U., Mondal N.K., Das K. \& Dutta S., 2012, An approach to polymer degradation through microbes. IOSR Journal of Pharmacy 2(3): 385-388.

Gibas E. \& Richert A., 2018, Ocena oddziaływania grzybów na folie oksy-degradowalne z biocydami, [w:] Polimery i Kompozyty Konstrukcyjne 2018, XVII Międzynarodowa Konferencja Naukowo-Techniczna, Szczyrk [Evaluation of the impact of mushrooms on the oxy-degradable films with biocides], [in:] Polymers and Structural Composites, 17th Internationl Scientific and Technical Conference, Szczyrk]. Stowarzyszenie Wychowanków Politechniki Śląskiej, Koło Materiałów Polimerowych i Metalowych w Gliwicach, Gliwice: 28 .

Hakkarainem M., Karlsson S. \& Albertsson A.C., 2000, Rapid (bio) degradation of polylactide by mixes culture of compost microorganisms-low molecular weight products and matrix changes. Polymer 41: 2331-2338.

Janczak K., Dąbrowska G., Hrynkiewicz K., Raszkowska-Kaczor A. \& Richert A., 2014, Selekcja grzybów zdolnych do wzrostu na tworzywach polimerowych, [w:] Mikrobiologia i Ochrona Środowiska, 48 Międzynarodowe Sympozjum, Warszawa [Selection of the fungi capable to growth on plastics, [in:] Microbiology and Environmental Protection, 48th International Symposium, Warsaw]. Urząd Marszałkowski Województwa Mazowieckiego, Warszawa: 55-56.

Jayasekara R., Harding I., Bowater I. \& Lonergan G., 2005 , Biodegradability of selected range of polymers an polymer blends and standard methods for assessment of biodegradation. Journal of Polymers and the Environment 13: 231-51.

Kumar S., Hatha A.A.M. \& Christi K.S., 2007, Diversity and effectiveness of tropical mangrove soil microflora on the degradation of polythene carry bags. Revista De Biologia Tropical 55(3-4): 777-786.

Levinskaitè L., 2018, Biodegradation Potential of Fungi Penicillium Isolated from Synthetic Polymeric Mate- 
rials. Journal of Environmental Engineering 144(7), art. no. 06018002. (doi: 10.1061/(ASCE)EE.1943$7870.0001391]$.

Libudisz Z., Kowal K. \& Żakowska Z., 2009, Mikrobiologia techniczna. Mikroorganizmy i środowiska ich występowania [Technical microbiology. Microorganisms and their environments]. Wydawnictwo PWN, Warszawa.

Manna A. \& Paul A.K., 2000, Degradation of microbial poliester poly(3-hydroxybuterate) in envirommental samples and in culture. Biodegradation 11: 323-329.

Morawska M. \& Krasowska K., 2017, Degradability of polylactide films by commercial microbiological preparations for household composters. Polish Journal of Chemical Technology 19(3): 44-48.

Nishida H. \& Tokiwa Y., 1993, Distribution of poly ( $\beta$-hydroxybutyrate) and poly( $\varepsilon$-caprolactone) aerobic degrading microorganisms in different environments. Journal of Environmental Polymer Degradation 1(3): 227-233.

PN EN ISO 846, 2014, Tworzywa sztuczne. Ocena działania mikroorganizmów [Plastics. Evaluation of the action of microorganisms].

PN EN 15457, 2014, Farby i Lakiery. Laboratoryjna metoda badania skuteczności w powłoce środków ochrony powłok przed grzybami [Paints and varnishes - Laboratory method for testing the effectiveness of the coating protective coating against fungi].

Qi X., Ren Y. \& Wang X., 2017, New advances in the biodegradation of Poly(lactic) acid. International Biodeterioration \& Biodegradation 117: 215-223.

Redlak K., Dahm H., Ciesielska A. \& Strzelczyk E., 2001, Enzymatic activity of ectendomycorrhizal fungi. Biology and Fertility of Soils 33: 83-90.

Rhim J.W., Hong S.I. \& Ha C.S., 2009, Tensile, water vapor barrier and antimicrobial properties of PLA/nanoclay composite films. LWT-Food Science and Technology 42: 612-617.
Richert A., 2017, Właściwości strukturalne i barierowe folii polilaktydowych z bakteriocynami po biodegradacji w ekstrakcie z kompostu [Structural and barrier properties of polylactide films with bacteriocins after biodegradation in a compost extract]. Przemysł Chemiczny 96/6: 1313-1316.

Shah A.A., Hasan F., Hameed A. \& Ahmed S., 2008, Biological degradation of plastics: A comprehensive review. Biotechnology Advanced 26: 246-265.

Shogren R., 1997, Water Vapor Permeability of Biodegradable Polymers. Journal of Environmental Polymer Degradation 2: 91-95.

Strömberg E. \& Karlsson S., 2009, The effect of biodegradation on surface and bulk property changes of polypropylene, recycled polypropylene and polylactide biocomposite. International Biodeterioration \& Biodegradation 63: 1045-1053.

Tokiwa Y. \& Calabia B.P., 2006, Biodegradability and biodegradation of poly(lactide). Appied Microbiology and Biotechnology 72(2): 244-251.

Torres A., Li S.M., Roussos S. \& Vert M., 1996, Screening of microorganisms for biodegradation of poly(lacticacid) and lactic acid-containing polymers Applied and Environmental Microbiology 62: 2393-2397.

Tsji H., Echizen Y. \& Nishimura Y., 2006, Enzymatic degradation of poly(L-Lactid Acid): Effects of UV irradiation. Journal of Polymers and the Environment 14: 239-248.

Wada Y., Seko N., Nagasawb N., Tamada M., Kasuya K.I. \& Mitomo H., 2007, Biodegradability of poly(3-hydroxybutyrate) film grafted with vinyl acetate: Effect of grafting and saponification. Radiation Physics and Chemistry 76: 1075-1083.

Żakowska H., Degradowalne opakowania z klasycznych tworzyw sztucznych, a opakowania kompostowalne z polimerów biodegradowalnych [Degradable packaging from classic plastics, and compostable packaging from biodegradable polymers]. Opakowanie 6: 20-25. 